\title{
DESIGN AND DEVELOPMENT OF MOTORIZED ACCIDENT PREVENTION TOOL USING ULTRASONIC SENSOR BASED ON ARDUINO UNO
}

\author{
Budi Prijo Sembodo $^{1}$, Oebet Rama Oktawiaci ${ }^{2}$ \\ Electrical Engineering Department, Faculty of Industrial Technology ${ }^{1,2}$ \\ University of PGRI Adi Buana Surabaya \\ email :budi@unipasby.ac.id
}

\begin{abstract}
Ultrasonic proximity sensor with a bluetooth headset is a tool that aims to minimize the number of accidents that often occur on the highway. With the aim of the importance of a tool that supports safety in carrying out activities in our daily lives, we drive. Ultrasonic proximity sensor with bluetooth headset has advantages in usage such as comfort, safety, and practicality. The method used in making this tool after finding the root of the problems that have been faced becomes an inspiration that is developed into a solution as outlined in a draft safety tool. For the development of this tool, it needs to be tested or monitored on the highway that is prone to accidents as a tool to improve this tool to function as a security tool. Improvement of this tool also requires a short time, in achieving improvement becomes a tool that can remind when driving. If our vehicle uses this tool, the road is prone to frequent accidents, being controlled by the distance that will be reminded through the sound coming out of the bluetooth headset
\end{abstract}

Keywords: ultrasonic sensor, bluetooth module headset, safety

\section{INTRODUCTION}

Along with the number of motorized vehicle users, the traffic flow becomes congested. This caused many motorcyclists to violate traffic signs or road markings. As a result, there are frequent accidents for violators of traffic regulations. Especially if you look at the mortality caused by accidents on vehicles from time to time is increasing. Body conditions that are tired and sleepy are also the cause of accidents while driving.

However, efforts to prevent accidents in driving are difficult to deal with seriously because they are related to driver awareness.
Therefore, efforts are made to minimize accidents by designing a security device that is attached to a motorcycle and driver, which is then connected to the bluetooth application. The purpose of this design is how to design a tool that can help minimize accidents when driving.

The benefits of the design of the device are: Tools that are very efficient and easy to use by motorcyclists when driving, and as an innovation motorcycle that is safe and comfortable in driving safety. In the design of this tool there is a formulation of the problem is to determine the distance of the ultrasonic sensor with other vehicles that are close together and determine the speed of the bluetooth connection when ultrasonic detects other vehicles that are close together and ensure the volume of sound by a Bluetooth headset.

\section{RESEARCH METHOD}

The product design on this tool is a device installed on a motorcycle system that includes a system on contact. The ultrasonic sensor device via Bluetooth has its own switch. This tool will function if there is a vehicle or object in front or back of a motorbike rider. An ultrasonic sensor that detects the distance of another vehicle will be sent to Arduino Uno to a Bluetooth transmitter and then received by a Bluetooth receiver and the headset sounds so that the driver knows of another vehicle nearby. The distance of the programmed ultrasonic sensor is $1.5 \mathrm{~m}$ with another vehicle.

The variables of this study are independent variables, motorized accident prevention devices and dependent variables include ultrasonic sensor distance, bluetooth speed, Bluetooth headset or sound output. 


\section{RESULTS AND DISCUSSION}

In this section the collection of test data is collected when a motorized accident device with a bluetooth headset uses an ultrasonic sensor when it is run. The data is presented in the form of tables or drawings / graphs. Among the results of the test are:

\section{Volt Battery Test and 9 volt battery}

12 volt batteries and 9 volt batteries are the power sources that will be used from this research tool. To determine the condition of batteries and batteries, it needs to be tested first before being used in research tools. The test is carried out by comparing the battery voltage value and the battery without the load with batteries and batteries that use the load. Writing the measurement results in the form of tables, the number value of the measurement results using avo meter. with the following results

Table 1. Accu and Battery Voltage Output Measurement

\begin{tabular}{lccc}
\hline No & Component & $\begin{array}{c}\text { Meaasurement Without load } \\
\text { (volt) }\end{array}$ & $\begin{array}{c}\text { Measurement Without load } \\
\text { (volt) }\end{array}$ \\
\hline 1 & Accu 12 v & 12.89 & 11.16 \\
2 & Battery 9v & 9.79 & 6.56 \\
\hline
\end{tabular}

After comparing the results of the voltage between no-load and the load obtained is a relatively small voltage difference.

\section{Arduino Uno test}

The Arduino test works to find out whether the pins on the Arduino board are working properly or not. The test is done by activating the led circuit on the Arduino pinpin board that is used for the circuit, then the Arduino board that has been connected to the LED circuit using the program on the IDE Arduino 1.6.3 software.

Table 2. Arduino Test

\begin{tabular}{ccc}
\hline Pin & Led & Voltage(Volt) \\
\hline 2 & On & 4.13 \\
3 & On & 4.17 \\
4 & On & 4.19 \\
5 & On & 4.05 \\
6 & On & 4.04 \\
7 & On & 4.04 \\
8 & On & 4.07 \\
9 & On & 4.03 \\
\hline
\end{tabular}

From the arduino board test results, it shows that the pins on the Arduino board have worked. The led circuit lights up together for 1 minute $(60000 \mathrm{~ms})$. The voltage value generated from each pin is different according to what is displayed by the measuring instrument avo meter.

\section{Ultrasonic Testing}

Ultrasonic sensor testing is done by connecting 4 legs, including VCC, TRIGER, ECHO, GROUND. The legs are connected to the arduino, the foot of the $\mathrm{VCC}$ is connected to the $5 \mathrm{~V}$ pin, the GND foot is connected to the GND pin, the TRIGER foot is connected to the 12 pin and the ECHO foot is connected to pin 13.

When testing the sensor can be seen in the Arduino IDE serial monitor that will display the distance of the object read by the Ultrasonic sensor. If the Multimeter is attached to the VCC PIN and the Ground and the object is placed according to a certain distance then the ultrasonic sensor works properly, the multimeter will show the voltage level on the multimeter screen and the distance on the arduino uno serial monitor. 


\section{Tibuana}

Journal of applied Industrial Engineering-University of PGRI Adi Buana

p-ISSN 2622-2027

$e$-ISSN 2622-2035

Table 3. Ultrasonic Testing

\begin{tabular}{cccc}
\hline Experiment & $\begin{array}{c}\text { Distance } \\
(\mathbf{c m})\end{array}$ & $\begin{array}{c}\text { Echo } \\
\text { (Volt) }\end{array}$ & $\begin{array}{c}\text { Vcc Sensor } \\
\text { (Volt) }\end{array}$ \\
\hline 1 & 10 & 0.340 & 4.98 \\
2 & 20 & 0.542 & 4.95 \\
3 & 30 & 0.757 & 4.95 \\
4 & 40 & 1.101 & 4.95 \\
5 & 50 & 1.247 & 4.95 \\
6 & 60 & 1.427 & 4.95 \\
7 & 70 & 1.588 & 4.96 \\
8 & 80 & 1.687 & 4.96 \\
9 & 90 & 1.835 & 4.96 \\
10 & 100 & 1.925 & 4.96 \\
11 & 110 & 2.039 & 4.96 \\
12 & 120 & 2.157 & 4.96 \\
13 & 130 & 2.525 & 4.96 \\
14 & 140 & 2.334 & 4.96 \\
15 & 150 & 2.425 & 4.96 \\
\hline
\end{tabular}

The test table proves that the ultrasonic sensor works well because it can detect objects according to distance and the voltage does not experience a drop.

\section{Bluetooth testing}

In Bluetooth testing it is necessary to know the ability to send and receive a program command. How to test bluetooth using the auto pairing method in which the bluetooth module can be connected automatically. However, the Bluetooth module is first set between master and slave.

Table 4. Bluetooth Testing

\begin{tabular}{ccc}
\hline $\begin{array}{c}\text { Distance } \\
\text { (Meter) }\end{array}$ & Second & $\begin{array}{c}\text { Vcc in Bluetoth } \\
\text { (Volt) }\end{array}$ \\
\hline 1 & 6 & 3.29 \\
2 & 12 & 3.17 \\
3 & 18 & 3.29 \\
4 & 24 & 3.20 \\
5 & 30 & 3.30 \\
6 & 36 & 3.29 \\
7 & 42 & 3.30 \\
8 & 48 & 3.30 \\
9 & 54 & 3.30 \\
10 & 60 & 3.30 \\
\hline
\end{tabular}

The test table above shows that the Bluetooth module can function and the voltage can be said to be stable.

\section{Overall Tool Testing}

Testing in this section is very important because it determines the success of this study. The test is carried out by direct observation and carried out when driving by carrying an avometer and stop watch. In order to produce sensor systems as well as data transfer via Bluetooth that can work well, a sensor distance variable is given to the object, the speed of the Bluetooth connection and the speed of the motorcycle that varies according to the needs 


\section{Tibuana}

Journal of applied Industrial Engineering-University of PGRI Adi Buana

of the motorbike rider. The speed variables used are:
a. Speed of $10 \mathrm{~km} /$ hour.
b. Speed of $20 \mathrm{~km} /$ hour.
c. Speed of $40 \mathrm{~km} /$ hour.
d. Speed of $60 \mathrm{~km} /$ hour.

e. Speed of $90 \mathrm{~km} /$ hour.

f. The following is a table of observations from the overall tool testing starting from a distance of 60 $\mathrm{cm}-120 \mathrm{~cm}$.

Table 5. Test With a distance of $60 \mathrm{~cm}$

\begin{tabular}{ccccccc}
\hline No & $\begin{array}{c}\text { Motor cycle Speed } \\
\text { Km/jam }\end{array}$ & Ultrasonic & Bluetooth & Buzzer & Led & Buzzer \\
& 10 & Connect & Connect & V & V & $0.007 \mathrm{v}$ \\
\hline 1 & 20 & Connect & Connect & v & v & $0.007 \mathrm{v}$ \\
2 & 40 & Connect & Connect & V & V & $0.007 \mathrm{v}$ \\
3 & 60 & Connect & Connect & v & v & $0.007 \mathrm{v}$ \\
4 & 90 & Connect & Connect & v & v & $0.007 \mathrm{v}$ \\
5 & & & & & &
\end{tabular}

Table 6 Test with a distance of $90 \mathrm{~cm}$

\begin{tabular}{ccccccc}
\hline No & $\begin{array}{c}\text { Motor cycle Speed } \\
\text { Km/jam }\end{array}$ & Ultrasonic & Bluetooth & Buzzer & Led & Buzzer \\
Voltage
\end{tabular}

Table 7 Test with a distance of $120 \mathrm{~cm}$

\begin{tabular}{ccccccc}
\hline No & $\begin{array}{c}\text { Motor cycle Speed } \\
\text { Km/jam }\end{array}$ & Ultrasonic & Bluetooth & Buzzer & Led & Buzzer \\
& & & & & Voltage \\
\hline 1 & 10 & Connect & Connect & v & V & $0.006 \mathrm{v}$ \\
2 & 20 & Connect & Connect & V & V & $0.006 \mathrm{v}$ \\
3 & 40 & Connect & Connect & v & V & $0.006 \mathrm{v}$ \\
4 & 60 & Connect & Connect & v & v & $0.006 \mathrm{v}$ \\
5 & 90 & Connect & Connect & v & v & $0.006 \mathrm{v}$ \\
\hline
\end{tabular}

From the results of the test table above it can be seen that the input voltage is 9volt and the buzzer output voltage obtained is 0.007 volt. 


\section{Tibuana}

Journal of applied Industrial Engineering-University of PGRI Adi Buana

p-ISSN 2622-2027

$e$-ISSN 2622-2035

\section{Data analysis}

Data analysis is as proof that the tool works well, indicated by the graph

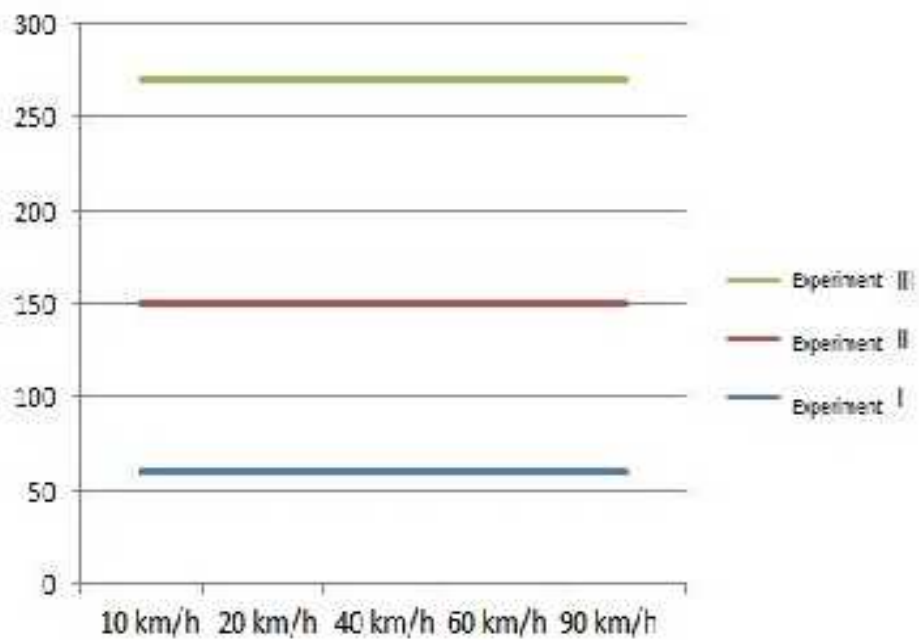

Figure 1. Ultrasonic Connection Distance Charts Against Distance and Speed

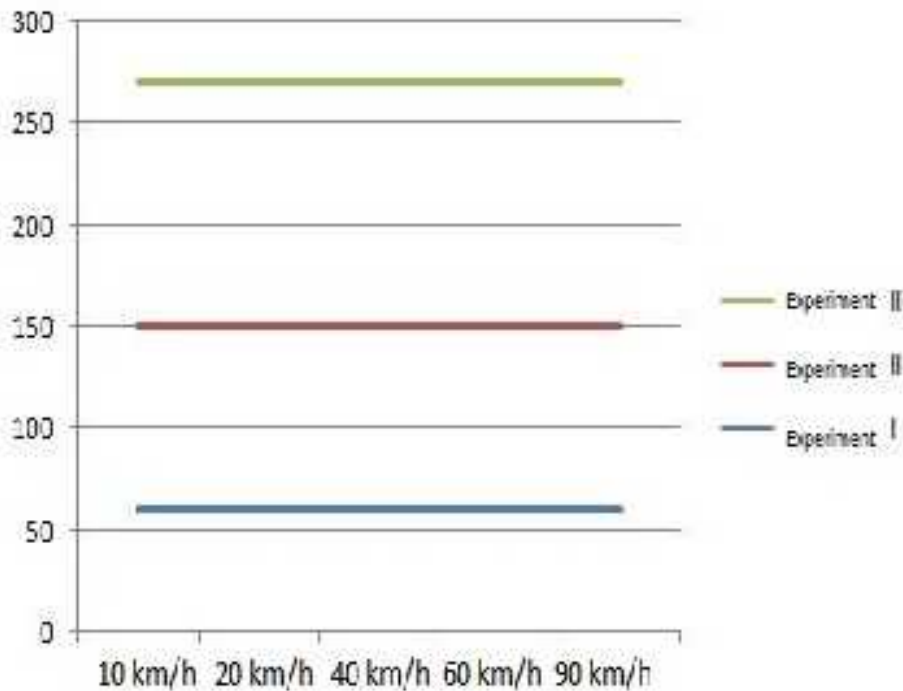

Figure 2 Graph of Bluetooth Connection Distance to Distance and Speed

\section{CONCLUSION}

From the discussion of the design and manufacture of motorized accident prevention devices using arduino uno-based ultrasonic sensors can be concluded:

\section{REFERENCES}

1. Dewi, R., \& Ramiati, 2010, The Making of Cordless Communication Modules uses Bluetooth Technology for Data Communication Practices in
1. Tools can work and can be connected according to plan.

2. Sound output that is less than optimal because the voltage is divided by the LED flame as an output other than the buzzer.

Telecommunications Laboratories, Electrical Engineering Journal Campus Unand Limau Manis Padang, Volume 2 No. 2. 
2. Diartono, D., A., 2009. Bluetooth technology for Internet services on Wireless Local Area Networks, DYNAMIC Information Technology Journal. Semarang. Vol. XIV, pp 70-78.

3. Djuandi, F., 2011. Introduction to Arduino. E-Book. Www.bobuku. July 2011. Accessed on July 202018.

4. Evangelos, V., Roch, G., Saswati, S., \& Jacob, R., 2005, Can Bluetooth Succed as a Large-Scale Ad Hoc Networking Technologist. IEEE Journal on selected areas in communications, Vol. 23, No. 3.

5. Kadir Abdul. Introduction to Electric Power Engineering. LP3ES. 1993
6. Kadir, A., 2013. Practical Guide to Learning Microcontroller Applications and Programming Using Arduino. Yogyakarta.C.V Andi Offset.

7. Guidelines and SOPs for the Final Project of the Faculty of Industrial Technology PGRI University Adi Buana Surabaya 2018.

8. Saefullah, A., Immaniar, D., \& Juliansah, R.A., Moving Moving Robot Control System Using Android Application Based on Arduino Uno.Journal of Electrical Sciences.Vol.8 No.2. January 2011.

9. Siswoyo.2008. Electric Power Engineering, Directorate of Vocational High School Development, Jakarta. 